\title{
Two endodontics techniques analysis in primary molars with fistula
}

\author{
Análise de duas técnicas endodônticas em molares decíduos fistulados
}

\author{
Regina Maura Coli SIEGL ${ }^{1}$ \\ Tathiane Larissa LENZI ${ }^{2}$ \\ Gabriel Tilli POLITANO \\ Monique De BENEDETTO' \\ José Carlos Petorossi IMPARATO' \\ Sérgio Luiz PINHEIRO3
}

\section{ABSTRACT}

\section{Objective}

The purpose of this research was to follow the radiolucent area (pixels) in the furcation area and the behavior of the endodontically treated deciduous molars with different simplified echniques.

\section{Methods}

The treatments were performed without the duct instrumentation using relative isolation and two drugs were applied, as follows: G1: GuedesPinto paste (GP) and G2: CTZ paste (CTZ) for the pulp chamber filling. The radiolucent areas in the furcation region of deciduous molars were obtained from previous $x$-rays, after 6 and 12 months of the endodontic treatment and was analysed by I Image Tool 3.0 by two blinded examiners. In order to analyse the calibration between the examiners, Kappa test was used and for comparison of the initial radiographic image, analysis of variance was used after 6 and 12 months of each group and Tukey spost-hoc test. T-Student test was used for comparison between groups.

\section{Results}

There was a reduction of radiolucent area after $6(p<0.01)$ and 12 months $(p<0.01)$ in the teeth treated with CTZ paste. In the teeth treated with PG there was not reduction of radiolucent area after 12 months. $(p=0,09)$.

\section{Conclusion}

Although the clinical signs were similar in both groups after 12 months of follow up, only teeth treated with CTZ showed reduction of radiolucent area in the furca area after 6 and 12 months.

Indexing terms: Primary tooth. Public health. Pulpectomy.

\section{RESUMO}

\section{Objetivo}

A proposta da pesquisa foi acompanhar a area radiolúcida (pixels) na região de furca e a resposta clínica de molares decíduos tratados endodonticamente com diferentes tecnicas simplificadas.

\section{Métodos}

Os tratamentos foram executados sem instrumentação dos condutos e com isolamento relativo, utilizando-se dois medicamentos: G1:Pasta Guedes-Pinto (PG) e G2: Pasta CTZ (CTZ) no preenchimento da câmara pulpar. As áreas radiolúcidas na região de furca dos molares decíduos obtidas das radiografias antes, após 6 meses e 12 meses do tratamento endodôntico foram analisadas no programa Image Tool 3.0 por 2 examinadores cegos. Para analisar a calibração entre os examinadores foi utilizado o teste Kappa e para comparação da imagem radiográfica inicial, após 6 e 12 meses de cada grupo foi utilizado a Análise de Variância e o teste complementar de Tukey. O teste T Student foi usado para comparação entre os grupos.

\section{Resultados}

A redução da área radiolúcida inicial após $6(p<0,01)$ e 12 meses $(p<0,01)$ foi observada somente com o uso da pasta CTZ. O emprego da pasta Guedes não resultou em diminuição da área radiolúcida após 12 meses de acompanhamento $(p=0,09)$.

\section{Conclusão}

A resposta clínica foi semelhante em ambos os grupos, porém apenas os dentes tratados com a pasta CTZ apresentaram redução da área radiolúcida na região da furca após 6 e 12 meses de acompanhamento.

Termos de indexação: Dente decíduo. Saúde Pública. Pulpectomia.

\footnotetext{
${ }^{1}$ Faculdade São Leopoldo Mandic, Curso de Odontopediatria, Departamento de Odontopediatria. Rua José Rocha Junqueira, 13, 13045-755, Campinas, SP, Brasil. Correspondência para / Correspondence to: M De BENEDETTO.E-mail: <moniquedebenedetto@gmail.com>

${ }^{2}$ Universidade Federal de Santa Maria, Faculdade de Odontologia. Santa Maria, RS, Brasil.

${ }^{3}$ Pontifícia Universidade Católica de Campinas, Faculdade de Odontologia. Campinas, SP, Brasil.
} 


\section{INTRODUCTION}

One of the major objectives of Pediatric Dentistry is to preserve primary teeth with caries or trauma alterations until their life cycle is complete, since early loss of these teeth can cause chewing, aesthetic and phonetic problems as well as contribute for malocclusion installation ${ }^{1 .}$

The artificial means used to keep the spaces of these precociously lost teeth have not always been effective, mainly when the loss of the 2 nd deciduous molar occurs, previously to the permanent molar eruption. On top of that, these means are not used in the desired frequency, especially by the public health service practioners who normally do not even offer preventive orthodontic care.

Despite the media reduction in DMFT in children, a survey in 2010 compared to 2003 showed that caries disease still affects a large part of the population and irreversible pulp alterations are frequent in Pediatric Dentistry ${ }^{2}$. In these situations, the endodontic treatment is the technique of choice.

Most of the techniques described in the literature $^{3-4}$ for the implementation of pulpectomy, recommends absolute/total isolation, odontometry, chemical-mechanical preparation of the ducts and filling, i.e. they are techniques that require competent practioners' performance as well as materials and instruments that are not always available in the public service. The simplified techniques proposed in the literature ${ }^{5-6}$ are based on the use of medicinal products which are placed on the pulp chamber floor, in order to eliminate the microorganisms presented there. Nonetheless these simplified procedures lack clinical and laboratory studies in order to present scientific based research so that they can be routinely carried out in Pediatric Dentistry.

Many are the users of the public health service requiring such treatment, but many of them have no choice but the extraction. Private practice can also be a possibility but unfortunately such treatment is often too pricey for this population.

The need to build up resources, without losing the quality of the treatment, causes the search for viable alternatives to the traditional existing dental practices ${ }^{7}$. Therefore, it becomes a challenge in pediatric dental endodontics seeking for simple and quick procedures but which can attain satisfactory both clinical and radiographic outcomes.

Therefore, the aim of this study was to follow the radiolucent area (pixels) in the furcation area and the behavior of the endodontically treated deciduous molars with two simplified tecnhiques.

\section{METHODS}

This study began after approval of the research project by the São Leopoldo Mandic Dental Ethics Committee Research Center, according to Resolution 196/1996 of CNS- Ministry of Health. A total of 28 children's primary molars, both genders, aged between 3 and 7 years old users who needed necropulpectomy were selected. They were assisted at the municipal public health center of the city of Serra Negra (SP), Brazil.

Inclusion criteria were: pulp necrosis clinically and radiographically evidenced by fistula by radiolucent area in the furcation region and integrity of bone crypt of the permanent successor. Children should participate in the research of their own free will, after clarification made by the researcher and signed the free and informed consent of their parents. The exclusion criteria was as follows: children with serious systemic problems, physical or mental disabilities as well as those whose teeth presented more than 1/3 of root resorption and extensive crown destruction preventing proper tooth restoration and finally the ones who refused to participate in the research.

The teeth $(n=28)$, after the initial radiographic examination (periapical technique), were randomly divided into two groups, as follows: it was previously agreed that patients and / or registered teeth with odd numbers would belong to Group I and those with even numbers would be in Group II. In both groups, the caries removal was performed with \# 4 spherical steel carbide bur at high speed under water cooling, and after complemented with \# 4 spherical steel carbide bur at low speed, also under water cooling.

The access to the pulp chamber was performed with a \# 4 diamond tip, followed by emptying the necrotic content until reaching the entrance of the duct, the teeth tissue removal and their duct enlarging ocurred as far as two millimeters with the aid of Kerr ${ }^{\circledR}$ files.

The relative isolation of the surgical field was obtained by means of cotton rolls and continuous use of sucking. Duct irrigation was carried out with $10 \mathrm{ml}$ of liquid Dakin's (0.5\% sodium hypochlorite), suction with the aid of hypodermic needles 25-6 and bore suckers. Following this procedure, the drying of the pulp chamber was performed using sterile cotton only in the first two millimeters with the aid of Kerr ${ }^{\circledR}$ files. 
The pulp chamber was then filled with the filling material, and pressure exerting so that the penetration would be just at the entrance of the ducts. The sealing of the pulp chamber was obtained with a thin layer of gutta percha (Dentsply Ind. Com. Ltda, Brazil).

All teeth were restored with resin modified glass ionomer (Vitremer ${ }^{\circledast}$ 3M Dental Products, St. Paul, MN, USA).

In the teeth belonging to Group I the material used for filling the pulp chamber was recommended by Guedes-Pinto et al. ${ }^{3}$ composed of iodoform, paramonochlorophenol camphor and Rifocort $^{\circledR}$ in equal parts. In Group II, the pulp chamber was filled with the paste described by Denari $\mathrm{CTZ}^{8}$ (a part of chloramphenicol $(500 \mathrm{mg})$ a portion of tetracycline $(500$ $\mathrm{mg}$ ) and two parts of zinc oxide type I, adding eugenol during manipulation.

\section{Radiograph imaging}

Periapical radiographs were taken with the Spectro unit (Dabi Atlante, Ribeirão Preto, SP, Brazil), calibrated to operate with $7 \mathrm{~mA}$ and $70 \mathrm{kVp}$, with 0.5 seconds film exposure time to $X$-rays. Kodak Insight (Rochester, NY, USA) were used for children's films. For the standardization of radiographs, autoclavable positioners for children's films (Indusbelo ${ }^{\circledR}$ mark (Industry dental instruments Ltda., Londrina, Brazil), were used, after adaptation of a heavy silicon layer in order to register the patient's bite impression on the selected tooth region ${ }^{5}$. The impressions were properly identified and stored.

Radiographs were taken immediately after treatment and the patients returned for further clinical and radiographic examinations after 6 and 12 months for follow-up, when new radiographs were taken in the same initial position, obtained by molding as the beginning of the treatment, adapted to the positioner. The adjustment in silicone molds was made after the final restoration, and cuts were made when necessary, in the region of the first permanent molar that eventually had erupted during follow-up time.

Periapical radiographs obtained at baseline, after 6 and 12 months were scanned (HP Scanner Scanjetxpa for high resolution) and later inserted into a computer program I Image Tool 3.0 (The University of Texas Health Science Center at San Antonio, TX, USA) allowing the demarcation of inter-radicular radiolucent area and its measure in pixels (Figure 1). The analysis was performed by two blinded examiners.

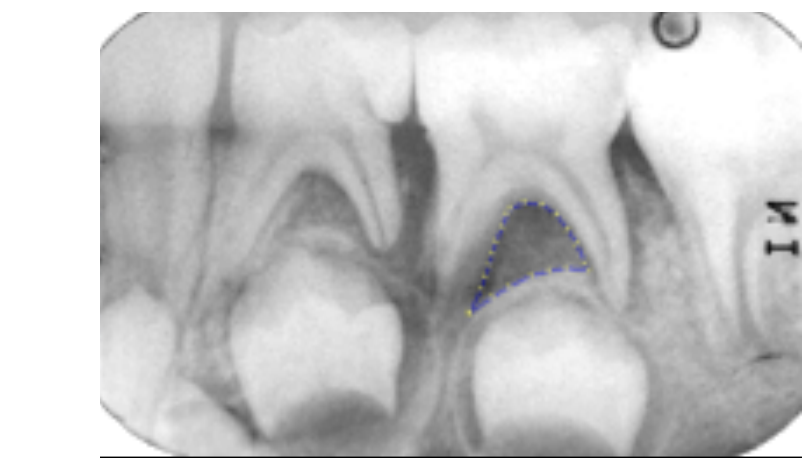

Figure 1. Measurement of radiolucent area in pixel.

\section{Statistical analysis}

The tooth was the experimental unit of the study. For each experimental group was considered the mean of the radiolucency of the furcation pixel of 10 teeth per group. The ANOVA and the complementary Tukey test were used to compare the initial results after 6 and 12 months of each experimental group. Comparisons between different groups were made with the Student $t$ test. The significance level was $5 \%$. The Kappa test was used to assess the intra- and inter-examiner. All analyses were performed using the statistical program MedCalc 12.1.3.0 (MedCalc Software bvba, Ostend, Belgium).

\section{RESULTS}

Of the 28 teeth with simplified endodontic treatment, only 10 of Group I (GP) and 10 Group II (CTZ) were included in the analysis due to loss of the sample.

Clinically, there was no fistula recurrence in any tooth treated in both groups after 12 months of follow-up. In the six months radiographic control, two teeth in Group I (GP) required extraction, due to increased radiolucid area. One of them had disruption of bone successor crypt and the other, resorption of the roots .

The reduction in the initial radiolucency after 6 $(p<0.01)$ and 12 months $(p<0.01)$ was observed only by using the paste CTZ (G2). The use of Guedes paste (G1) did not result in decreased radiolucency after 12 months of follow-up $(p=0.09)$. The means and standard deviations for all experimental groups are shown in Table 1. Examiners showed good inter- (Kappa $=0.81 \mathrm{Ex} 1$; Ex $2=0.90)$ and agreement (Kappa $=0$ Ex1-2, 82). The radiographic follow-up of both $G 1$ and $G 2$ cases are further shown in Figure 2. 
Table 1. Mean and standard deviations of radiolucency in the furcation region to all groups(*)

\begin{tabular}{ccc}
\hline Time vs Group & Guedes-PintoPaste & CTZ Paste \\
\hline Initial & $5732,2 \pm 334,6^{\mathrm{A}}$ & $5048,3 \pm 306,4^{\mathrm{A}}$ \\
6 months & $4614,8 \pm 353,6^{\mathrm{A}}$ & $2578,4 \pm 258,4^{\mathrm{B}}$ \\
12 months & $4528,1 \pm 412,9^{\mathrm{A}}$ & $2267,5 \pm 324,1^{\mathrm{B}}$ \\
\hline
\end{tabular}

$(*)$ Different overwritten capital letters indicate statistically significant differences $(p<0,05)$.

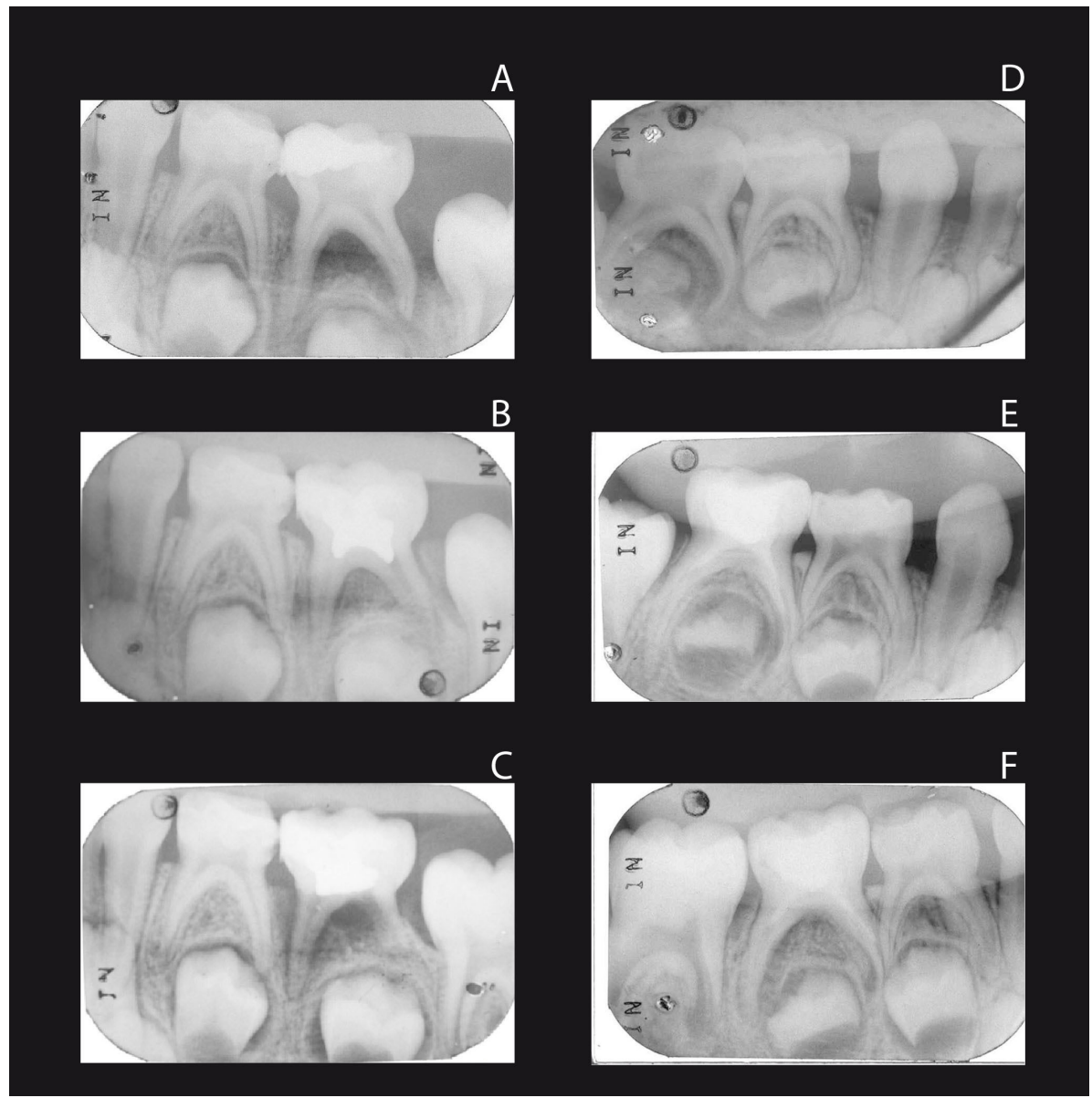

Figure 2. Radiographic Follow-treated teeth with Guedes-Pinto paste (G1): A - initial radiographic image, B - radiographic image after 6 months of endodontic treatment and C - radiographic image after 12 months of endodontic treatment. The imagens D, E and F correspond to the radiographic follow-up of treated teeth with CTZ Paste (G2) D - Initial radiographic image, E - radiographic image after 6 months of endodontic treatment and F- radiographic image after 12 months of endodontic treatment.

\section{DISCUSSION}

Facing the various endodontic techniques for primary teeth described in the literature, Barcelos et al. ${ }^{9}$ performed a systematic review of the literature in relation to clinical and radiographic successful pulpectomy performed with the paste based on zinc oxide and eugenol and other materials after 12 months or more follow-up. Of the 43 articles identified, only 15 met the inclusion criteria and of these only two were selected as presenting both qualified characteristics and results. The authors concluded that the results were similar between the zinc oxide eugenol and pastes, based on iodoform and calcium hydroxide. There is no evidence supporting the superiority of either filling material after pulpectomy in deciduous teeth.

Oliveira \& $\operatorname{Costa}^{10}$ in their retrospective study of 40 endodontically treated teeth with CTZ paste reported $29.1 \%$ success rate. This prospective clinical research which potentially was less likely to be biased, showed increased bone formation in the furcation region when using the CTZ paste, compared to Guedes-Pinto paste after 12 months. However, it is noteworthy that Guedes-Pinto paste was 
applied only in the pulp chamber without the complete filling of the root canal, as it is indicated in pulpectomy technique. In deciduous molars, the topographic complexity characterized by interconnecting canals with side branches and junctions or apical ramifications, added to the resulting morphology of root resorption, does not offer safety and accuracy ${ }^{11-13}$.

When it comes to public health, most of the time, resources are scarce, which often leads dentists to perfom procedures which are far from the ideal ones, for example, extraction of teeth which could receive appropriate treatment. It is therefore in Pediatric Dentistry, a challenge to search for simpler procedures where absolute isolation, odontometry and instrumentation of the ducts are dismissed, but which could provide both clinical and radiographic satisfactory result in the end.

The objective of this study was to replicate what has been done in some municipalities in Public Health centers concerning endodontic treatment of teeth presenting pulp necrosis, diagnosis where the pulpectomy is often not carried out according to the techniques recommended in the literature, for lack of $x$-rays equipment and instruments, impairing odontometry and instrumentation required in most techniques.

Therefore, in the present research, we have chosen to use the CTZ paste, for histological and microbiological studies attest its biocompatibility and wide antimicrobial potential ${ }^{14-16}$. Moreover, Giro et al. ${ }^{17}$ have indicated this technique to cases where there has been a very doubtful prognosis, or even when the technique recommended by them had been used without any regression signs and symptoms.

The literature shows different proportions of the drugs used in the CTZ paste. While Capiello ${ }^{18}$ used the same quantities of chloramphenicol, tetracycline and zinc oxide, Denari ${ }^{8}$, Spinning et al. ${ }^{17}$ suggested a ratio of 1 : 1 : 2 , respectively. In this research, we have chosen the least amount of antibiotic, once the above authors stated that in this concentration, the paste has already been successful for over 40 years.

In the other group was used the Guedes-Pinto paste, since it has been the most used one by Brazilian colleges $^{19}$, in addition to its proven biocompatibility and good antibacterial activity ${ }^{14-15,20}$. The technique proposed by Guedes- Pinto et al. ${ }^{3}$ has been simplified to suit the public service conditions.

According to Guedes-Pinto et al. ${ }^{3}$, after treatment of 45 primary necrotic molars, clinical and radiographic success was observed in $98 \%$ of cases, the authors credited this mainly to the chemical action and pulp filling. The results found by Puppin-Rontani et al. ${ }^{21}$, which also followed clinically and radiographically 23 necrotic primary teeth, 17 of them with bone thinning in the region of furcation, had $82 \%$ success rate at 6 months and $64 \%$ in 12 months. According to Mello-Moura et al. ${ }^{22}$ once these studies, show high technical successful rates, GuedesPinto paste can be consolidated as the elected material for endodontic treatment of deciduous teeth.

Gomes et al. ${ }^{12}$ found the bacterial presence in $100 \%$ of primary necrotic teeth after biomechanical preparation of the ducts. The culture was still positive in $52 \%$ of these teeth, seven days after being treated with Guedes-Pinto paste. This study helps to understand the results obtained and it was inferred that the absence of the chemical-mechanical preparation together with not filling the ducts substantially, increases the possibility of failure ${ }^{12}$. Microbiological analysis of primary necrotic teeth show that the present infection is polymicrobial, since Gram negative and Gram positive, aerobic, black pigmented bacteria were found with a higher prevalence of strict anaerobes and Streptococcus ${ }^{23}$.

Higher clinical and radiographic efficiency of CTZ paste compared to Guedes-Pinto paste found in this study, can be explained by antimicrobial action. The CTZ paste displays antimicrobial effects mainly due to the two broad-spectrum antibiotics action: tetracycline, whose antimicrobial activity includes Gram-positive and Gram-negative (both aerobic as anaerobic), although its main activity is against the Gram-positive microorganisms and chloramphenicol, it also presents a broad antibiotic spectrum acting against Gram-negative bacteria, some streptococci and most anaerobic ${ }^{24}$. Guedes Pinto paste, in turn, presents the rifamycin, a surface antibiotic, acting on Gram positive and Gram negative and the camphorparamonochlorophenol acts against anaerobic bacteria. Although the two pastes present other antibacterial components, Amorim et al. ${ }^{14}$ concluded that CTZ paste was the one with the best microbial efficiency in vitro. Another possibility that would explain the greater effectiveness of CTZ paste based on the slow rate of absorption by containing zinc oxide in the formula ${ }^{23}$, unlike the Guedes-Pinto paste, allowing longer drug contact time with the affected region.

Gomes et al. ${ }^{12}$ stated that the lipopolysaccharide cell wall of Gram-negative bacteria to be the determinant of pathogenicity, triggering inflammatory and immunopathological responses that lead to the development of periapical lesions. Because the chloramphenicol 
solubility, it is highly and widely distributed in tissues and body fluids, causing the antimicrobial effectiveness of CTZ paste. This chloramphenicol characteristics not pertinent to short-acting tetracyclines (tetracycline and oxytetracycline) which therefore brings lower capacity to invade tissues and body fluids ${ }^{24}$.

Clinical success, evidenced by the absence of pain and mobility and the regression of the fistula in 100\% of cases in both groups, corroborates with the results found by Guedes-Pinto et al. ${ }^{3}$ and Puppin-Rontani et al. ${ }^{21}$, and shows that frequently it does not go along with radiographic success.

The Public Health Centers in Brazil lack simplified treatment protocols, which can be performed by the general practitioner, reducing the demand for certain dental treatments. It is understood that more studies need to be done in this direction so that health

\section{REFERENCES}

1. Khairwa A, Bhat M, Sharma R, Satish V, Maganur P, Goyal AK. Clinical and radiographic evaluation of zinc oxide with aloe vera as an obturating material in pulpectomy: an in vivo study. J Indian Soc Pedod Prev Dent. 2014;32(1):33-8. doi: 10.4103/09704388.127051

2. Brasil. Ministério da Saúde. Secretaria de Atenção à Saúde. Secretaria de Vigilância em Saúde. SB Brasil 2010: Pesquisa Nacional de Saúde Bucal - Resultados principais. Brasília: Mnistério da Saúde; 2012 [citado 2014 Out 10]. Disponível em: < http://bvsms.saude.gov.br/bvs/publicacoes/pesquisa_ nacional_saude_bucal.pdf>

3. Guedes-Pinto AC, Paiva JG, Bozzola JR. Tratamento endodôntico de dentes decíduos com polpa mortificada. Rev Assoc Paul Cir Dent. 1981;35(3):240-5.

4. Rifkin A. A simple, effective, safe technique for the root canal treatment of abscessed primary teeth. ASDC J Dent Child. 1980;47(6):435-41.

5. Coser RM. Tratamento endodôntico de molares decíduos humanos com necrose pulpar e lesão periapical. Rev Fac Odontol São José dos Campos. 2002;(5):84-92.

6. Takushige T, Cruz EV, Asgor-Moral A, Hoshino E. Endodontic treatment of primary teeth using a combination of antibacterial drugs. Int Endod J. 2004;37(2):132-8. doi: 10.1111/j.01432885.2004.00771.x

7. Pizzatto E, Garbin CAS, Garbin AJI, Saliba NA. Uma alternativa viável em saúde pública para a confecção do isolamento absoluto. J Bras Clin Odontol Int. 2002;6(34):318-20.

8. Denari W. CTZ. Rev Assoc Paul Cirurg Dent. 1996;20(2):186-7. professionals can perform safe procedures, grounded in scientific evidence.

\section{CONCLUSION}

The clinical response was similar in both groups, but only the teeth treated with CTZ paste had reduced radiolucent area at the furcation after 6 and 12 months of follow-up.

\section{Collaborators}

RMC SIEGL was in charge of most parts of this manuscript writing and research. TL LENZI in charge of statistics. M BENEDETTO and GT POLITANO they were responsible for the final review of the article. SL PINHEIRO and JCP IMPARATO research advisors. All the Authors were deeply involved in the manuscrit writing

9. Barcelos R, Santos MP, Primo LG, Luiz RR, Maia LC. ZOE paste pulpectomies outcome in primary teeth: a systematic review. J Clin Pediatr Dent. 2011;35(3):241-8.

10. Oliveira MA, Costa LRRS. Desempenho clínico de pulpotomias com pasta CTZ em molares decíduos: estudo retrospectivo. Robrac. 2006;15(40):50-62.

11. Bagherian A, Kalhori KA, Sadeghi M, Mirhosseini F, Parisay I. An in vitro study of root and canal morphology of human deciduous molars in an Iranian population. J Oral Sci. 2010;52(3):397-403. doi: 10.2334/josnusd.52.397

12. Gomes AM, Fonseca L, Guedes-Pinto AC. Avaliação microbiológica do preparo biomecânico e de uma pasta obturadora de canais de dentes decíduos necrosados. Rev Odontopediatr. 1997;3(5):93-101.

13. Walia T. Pulpectomy in hyperemic pulp and accelerated root resorption in primary teeth: A review with associated case report. J Indian Soc Pedod Prev Dent. 2014;32(3):255-61. doi: 10.4103/0970-4388.135844

14. Amorim LFG, Toledo AO, Estrela CRA, Decurcio DA, Estrela C. Antimicrobial analysis of different root canal filling pastes used in pediatric dentistry by two experimental methods. Braz Dent J .2006;17(4):317-22. doi: 10.1590/S0103-64402006000400010

15. Bruno GB, Abreu APN, Menezes VA, Maia MCG, Bruno JA, Viana GSB. Biocompatibility evaluation of anantibiotic paste after pulpotomy in dogs. Braz J Oral Sci. 2007;6(22):1397-401.

16. Lima CCB, Conde Júnior AM, Rizzo MS, Moura RD, Moura MS, Lima $M D$, et al. Biocompatibility of root filling pastes used in primary teeth. Int Endod J. 2015;48(5):405-16. doi: 10.1111/iej.12328

17. Giro EMA, Helbing J, Bausells J. Tratamento endodôntico em dentes decíduos. In: Bausells J. Odontopediatria: procedimentos clínicos. São Paulo: Ed. Premier; 1997. p.139-53. 
18. Capiello J. Tratamientos pulpares en incisivos primarios. Rev Assoc Odont Argentina.1964;52(4):139-45.

19. Corrêa Brusco EH, Perussolo B, Scapin HLC, Ferreira SLM Procedimentos e substâncias empregadas por faculdades de odontologia brasileiras na terapia endodôntica de dentes decíduos pulpectomizados. J Bras Odontop Odontol Bebe. 2002;5(23):35-46.

20. Cerqueira DF, Mello-Moura AC, Santos EM, Guedes-Pinto AC. Cytotoxicity, histopathological, microbiological and clinical aspects of an endodontic iodoform-based paste used in pediatric dentistry: a review. J Clin Pediatr Dent. 2008;32(2):105-10.

21. Puppin-Rontani RM, Peters CF, Worliczek AM. Tratamento endodôntico de dentes decíduos com necrose pulpar. Rev Assoc Paul Cir Dent. 1994;48(1):1235-8.
22. Mello-Moura ACV, Cerqueira DF, Santos EM. Pasta Guedes-Pinto: revisão de literatura: 26 anos de estudos sobre citotoxidade, citotóxicos, histopatológicos, microbiológicos e clínicos. RPG Rev Pós Grad. 2007;14(3):260-6.

23. Reddy S, Ramakrishna Y. Evaluation of antimicrobial efficacy of various root canal filling materials used in primary teeth: a microbiological study. J Clin Pediatric Dent. 2007;31(3):195-9.

24. Silva P. Farmacologia. $4^{\text {a }}$ ed. Rio de Janeiro: Guanabara Koogan; 1994.

Received on: 25/10/2014

Final version resubmitted on: 7/12/2014

Approved on: 15/3/2015 
